DOI https://doi.org/10.18551/rjoas.2018-04.32

\title{
INTERMEDIATE PROCESSED COCOA CONTRIBUTION TO INDONESIAN FOREIGN EXCHANGE
}

\author{
Rahmawiliyanti* \\ Postgraduate Program in Agriculture Science, interest of Agricultural Economy, \\ Agricultural Faculty, Brawijaya University, Indonesia \\ Hanani Nuhfil, Anindita Ratya, Syafrial \\ Department of Agribusiness, Agricultural Faculty, Brawijaya University, Indonesia \\ *E-mail: leni.ilma@yahoo.com
}

\begin{abstract}
Cocoa is a non-oil commodity export commodity from the plantation sub-sector that became one of the third largest contributors of foreign exchange after palm oil and rubber. Cocoa exports in order to increase export value are concentrated on intermediate processed cocoa, namely cocoa paste, cocoa butter and cocoa powder. The objectives of this research are to analyze the contribution of intermediate processed cocoa products in generating foreign exchange and the factors that affect foreign exchange of Indonesian cocoa. Data analysis used descriptive statistics and inferential statistics. The model is estimated by multiple regression equation with Ordinary Least Square method. The results state that cocoa paste, cocoa butter and cocoa powder have the potential to increase Indonesia's cocoa foreign exchange. The production volume of cocoa beans, the price of world cocoa beans, the world price of cocoa paste and the world price of cocoa powder are the factors that can affect the foreign exchange of Indonesian cocoa. Intensive programs are needed to improve the quantity and quality of cocoa beans and intermediate processed cocoa so that Indonesian cocoa exports foreign exchange increased.
\end{abstract}

\section{KEY WORDS}

Foreign exchange, cocoa beans, cocoa butter, cocoa paste, cocoa powder.

Every country in the world can be assured to trade with other countries, either in the form of export and import activities. The activity is done because not all the needs of the country can be met by the state itself. Through specialization in trade will be obtained profits that became the main goal in a trade.

Indonesia is one of the countries that active in the world trade. Export is one of the important source of economic growth for Indonesia. Non-oil export activities are the government's efforts to create sustainable economic growth. Cocoa is one of the non-oil and gas commodity that become the pride of Indonesia. Cocoa is the export commodity which is the third largest contributors of foreign exchange from the plantation subsector after the oil palm and rubber.

Most of the foreign exchange earned from the export of cocoa beans, because of undeveloping cocoa downstream products. There is a government policy in 2010 that restrict the export of cocoa beans to fullfil the needs of the downstream industry of cocoa which is one of the government's priorities to be developed. The shift of export policy from raw material to semi-finished material raises a question that should be studied further, that is whether intermediate processed cocoa beans can contribute in generating foreign exchange.

Muthamia A.K. and Muturi W. (2015) examined the exploration of the exchange rate, inflation and overseas earnings of major trading partners to tea export earnings. Control variables include tea unit price, value added agriculture and exports of goods and services. Various regression methods are used, ie root test, co integration, and error correction model. Foreign revenues have an indirect relationship with tea export earnings and inflation has no effect. There is a direct relationship between tea export earnings and exchange rate values, 
tea prices, exports of goods and services, and the addition of agricultural value. This study recommends tea exporters to hedge against foreign exchange rate risk through derivatives. Stakeholders should be involved in marketing and adding value to agriculture. The addition of agricultural value is an ongoing solution to ensure income stability from tea export in the country.

Mehrjerdi M.Z. et al (2016) examined the pistachio which is one of the main export products of foreign exchange in Iran. This review assesses the factors that affect the instability of export earnings (foreign exchange) pistachio and its effect on agricultural exports during the study period. For this purpose, the index of foreign exchange instability is calculated using the average absolute difference between export earnings and trends. The Vector Error Correction Model (VECM) is used to estimate the model during the period 19732010. The results indicate that the pistachio concentration index has a negative effect, but the instability of pistachio products and exchange rate gaps have a direct relationship with the instability of pistachio foreign exchange. The results of estimates of the agricultural export function indicate that the instability of pistachio foreign exchange has a negative and significant impact on agricultural exports.

The foreign exchange research of intermediate processed cocoa is done using the approach of factors affecting exports. Based on the change of government policy in cocoa economy, the purpose of this research are to analyze the contribution of intermediate processed cocoa products, namely: cocoa paste, cocoa butter and cocoa powder in generating foreign exchange. and the factors affecting foreign exchange of Indonesian cocoa

\section{METHODS OF RESEARCH}

This study uses secondary data from 1992 to 2015 related to price, export volume of cocoa beans and intermediate processed cocoa, namely: cocoa paste, cocoa butter and cocoa powder. Source of data comes from Ditjenbun, Trademap, UN Comtrade.dan FAO.

Descriptive statistical analysis and t-test are used to answer the first objective: to analyze the contribution of cocoa paste, cocoa butter and cocoa powder in generating foreign exchange. Multiple regression analysis is used to answer the second goal is to determine the factors that affect the foreign exchange of Indonesian cocoa

Foreign exchange of Indonesian cocoa is the sum of the value of cocoa beans export and intermediate processed cocoa export. The equation of Indonesian cocoa foreign exchange is as follows:

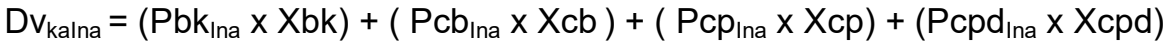

$$
\begin{aligned}
& D v_{\text {kalna }}=a_{0}+a_{1} Q b k+a_{2} P \text { k }_{\text {Ina }}+a_{3} P c P_{\text {Ina }}+a_{4} P_{c b} b_{\text {Ina }}+a_{5} P c p d_{\text {Ina }}+U
\end{aligned}
$$

Where:

- $D v_{\mathrm{ki}}=$ The foreign exchange of Indonesian cocoa;

- $\mathrm{Xbk}=$ Cocoa beans export;

- $\mathrm{Xcb}=$ Cocoa butter export;

- $\mathrm{Xcp}=$ Cocoa paste export;

- $\quad \mathrm{Xcpd}=$ Cocoa powder export;

- $\quad$ Qbk = Cocoa beans production;

- Pbklna = The Price of Indonesian cocoa beans;

- $\quad$ Pcplna = The Price of Indonesian cocoa paste;

- $\quad$ Pcblna = The Price of Indonesian cocoa butter;

- $\quad$ Pcpdlna = The Price of Indonesian cocoa powder;

- Ina = Indonesia.

The foreign exchange of Indonesian cocoa model is estimated by multiple regression equation and Ordinary Least Square method is used to measure its parameters. Allegedly, all parameters of a1, a2, a3, a4 and a5 are positive. 


\section{RESULTS AND DISCUSSION}

The value of foreign exchange for cocoa beans and intermediate processed cocoa fluctuated, which tends to increase until 2010. Foreign exchange from cocoa beans experienced an extreme increase occurred in 1998, 2002, 2008, 2009 and after 2010 is the enactment of Minister of Finance Regulation No. PMK. 67 / PMK.011 / 2010 about the export of cocoa beans restriction, the contribution of foreign exchange from cocoa beans has decreased. The fall in foreign exchange in 2011 was due to lower export volumes due to very high rainfall.

The foreign exchange value of intermediate processed cocoa continues to increase cocoa butter, cocoa paste and cocoa powder. The increase of foreign exchange value of intermediate processed cocoa exports is due to the increasing of the government role in stimulating downstream products and the increasing demand of intermediate processed cocoa from importing countries.

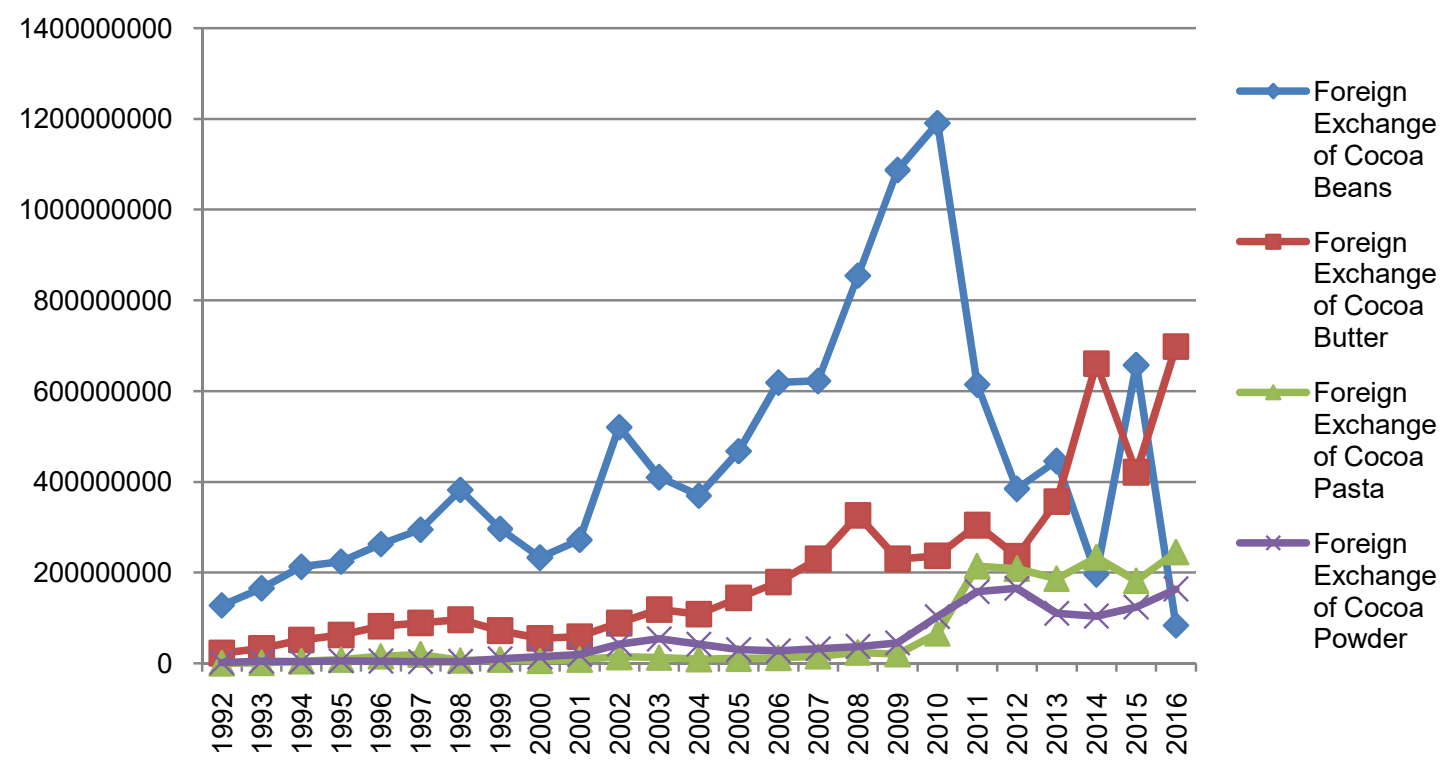

Figure 1 - Foreign Exchange from Cocoa Beans, Cocoa Butter, Cocoa Paste and Cocoa Powder

Before cocoa beans exports restrictions, the export of cocoa beans is the largest contributor to the foreign exchange than processed cocoa. Graphically, figure 1 reflects the foreign exchange of cocoa beans and foreign exchange of each intermediate processed cocoa, ie foreign exchange of cocoa paste, foreign exchange of cocoa butter and foreign exchange of cocoa powder. After 2010 there was a decline in the value of cocoa beans and the increase of each intermediate processed cocoa foreign exchange. Figure 2, by the trendline, it can be clearly seen that there is a decrease in cocoa bean foreign exchange and the increase of foreign exchange rat from intermediate processed cocoa which is the sum from the foreign exchange of cocoa paste, cocoa butter and cocoa powder.

The average of foreign exchange of intermediate cocoa is higher than cocoa beans, but statistically after the t-test, the difference of the value of foreign exchange after the implementation of the regulation of Finance Minister in 2010 is not significantly different. After the export restriction of cocoa beans, the export volume of cocoa beans decreased (figure 3 ), but the value of foreign exchange was relatively high. This is presumably because the exported cocoa beans are the premium type with a high price. This premium quality cocoa beans comes from large plantations (government and private) and is also the product of a particular production area that is not mixed with products from other regions.

The increasing of Indonesian cocoa foreign exchange can be seen from the factors that influence it. Based on the analysis results of foreign exchange function model of Indonesia cocoa can be identified the factors that influence it. 


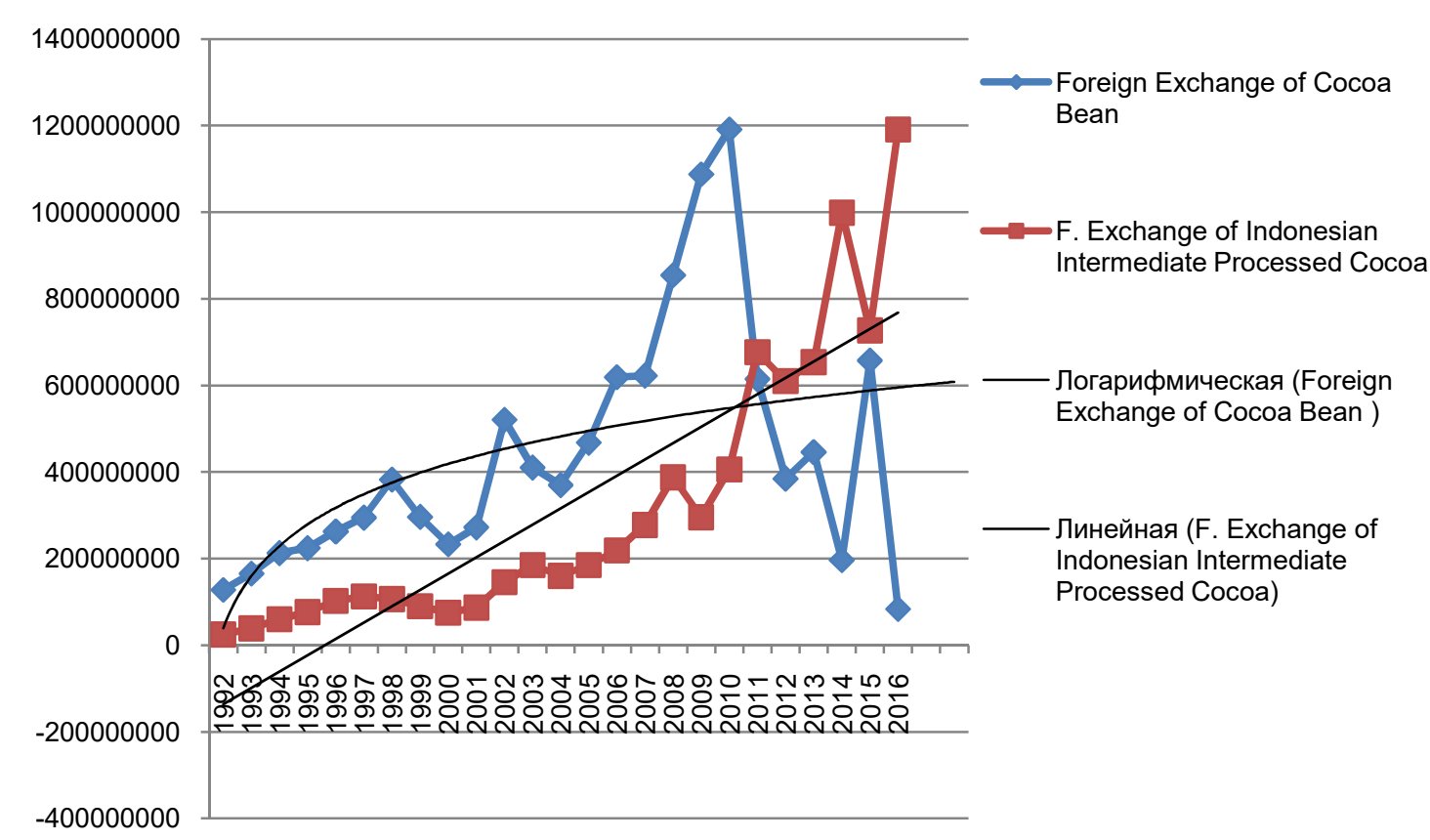

Figure 2 - Foreign Exchange of Cocoa Bean and Indonesian Intermediate Processed Cocoa

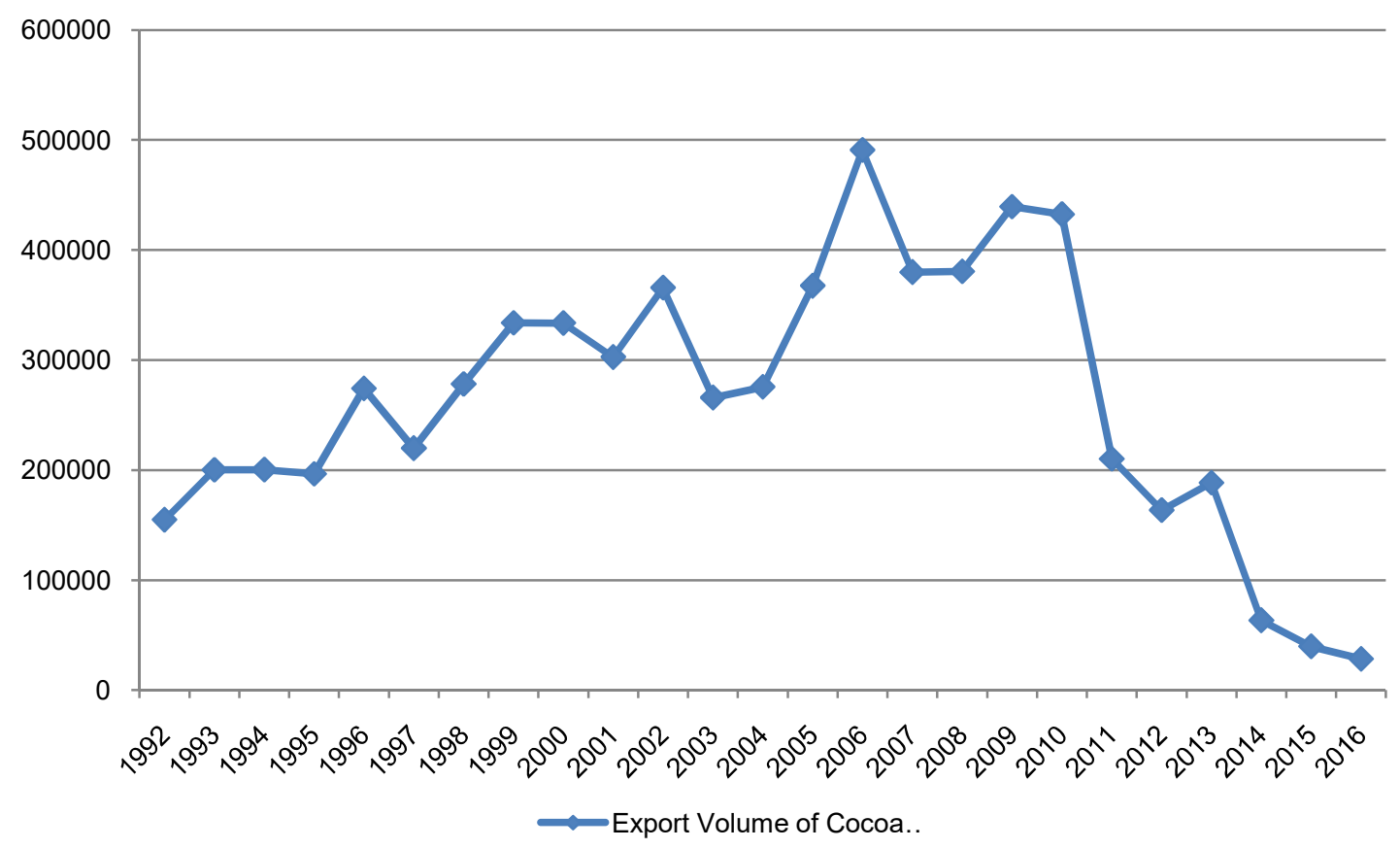

Figure 3 - Export Volume of Cocoa Beans Period 1992-2015

Table 1 - T-Test on Cocoa Beans and Intermediate Processed Cocoa after the Applied Export Restrictions

\begin{tabular}{ccc}
\hline & Foreign Exchange of Cocoa Bean & $\begin{array}{c}\text { Foreign Exchange of Cocoa } \\
\text { Intermediate Processed Cocoa }\end{array}$ \\
\hline Mean & $581,700,393.83$ & $678,749,331.83$ \\
$\mathrm{t}$ Stat & -0.606657935 & \\
$\mathrm{P}(\mathrm{T}<=\mathrm{t})$ one-tail & 0.278799415 & \\
$\mathrm{P}(\mathrm{T}<=\mathrm{t})$ two-tail & 1.812461123 & \\
$\mathrm{t}$ Critical two-tail & 0.557598829 & \\
\hline
\end{tabular}

Source: Secondary Data Analysis. 
Table 2 - The Statistical Analysis Estimation of Factors Affecting Indonesian Cocoa Foreign Exchange

\begin{tabular}{llcl}
\hline Variable & Coefficient & t-Value & Significant \\
\hline & & & \\
Intercept & $-5.456 \mathrm{E} 8$ & -7.631 & .000 \\
Indonesian Cocoa Beans Production & 766.660 & 6.385 & .000 \\
The World Price of Cocoa Beans & 73204.110 & 2.633 & .017 \\
The World Price of Cocoa Paste & 272055.012 & 2.480 & .023 \\
The World Price of Cocoa Butter & 22279.543 & .564 & .580 \\
The World Price of Cocoa Powder & -126402.341 & -1.933 & .069 \\
\hline
\end{tabular}

$F$ Value $=141.900($ Sig. $=.000) R$ square $=.975$

The statistic test results of Indonesian cocoa foreign exchange show that exogenous variables used in the model have a chance to explain $97,50 \%$ variation of endogenous variables and the rest of $2.50 \%$ influenced by other variables do not use in the model.

F-value is 141,900 with $0,00 \%$ error rate. It indicates that simultaneously Indonesian cocoa foreign exchange is affected by cocoa beans production, the world price of cocoa beans, the world price of cocoa paste, the world price of cocoa butter and the world price of cocoa powder.

Partially, Indonesian cocoa foreign exchange is influenced by cocoa beans production with $0 \%$ significance level, the world price of cocoa beans with $1,7 \%$ significance level, the world price of cocoa paste with 2,3\% significance level, the world price of cocoa powder with $6,9 \%$ significance level and negative relationship direction.

Cocoa beans are the basic ingredients of intermediate processed cocoa. Production volume of cocoa beans, not only affects the amount of cocoa beans export, but also affects the export derivative of cocoa beans, ie the intermediate processed cocoa. The high production volume of cocoa beans will increase the production and export of intermediate processed cocoa, so that the Indonesian intermediate processed cocoa foreign exchange will increase. This is in accordance with the direction of a positive relationship in the model, which implies that the higher the production volume of cocoa beans, the higher the Indonesian cocoa foreign exchange.

As well as Muthamia A.K research. and Muturi W state that world price of tea affect tea foreign exchange, rising world cocoa beans price can also stimulate export and increase foreign exchange of Indonesian cocoa.

Increasing world price of cocoa paste does not affect importer countries to decrease import of cocoa paste, thus, increasing world price of cocoa paste will increase the foreign exchange of Indonesian cocoa.

The amount of cocoa powder export volume is determined by how much cocoa powder demand from importing countries. The high world price of cocoa powder will decrease demand of cocoa powder from importer countries, thus reducing Indonesia cocoa powder export, thereby reducing the foreign exchange of Indonesian cocoa.

\section{CONCLUSION}

Processed intermediate cocoa, i.e cocoa paste, cocoa butter and cocoa powder have the potential to increase Indonesian cocoa's foreign exchange. The production volume of cocoa beans, the world price of cocoa beans, the world price of cocoa paste and the world price of cocoa powder are the factors that can affect the foreign exchange of Indonesian cocoa. Required intensive government support in the form of programs that can increase the production and quality of cocoa beans to fullfil the domestic needs of intermediate processed cocoa industry, so that the quality and export of processed intermediate cocoa increases, thus improving the foreign exchange of Indonesian cocoa. 


\section{REFERENCES}

1. Ditjenbun, 2014. Statistik Perkebunan Indonesia, Kakao 2013-2015, ditjenbun.pertanian.go.id.

2. FAO, Food and Agriculture Organization of the United Nations, www.fao.org.

3. Mehrjerdi M.Z., Azizi Z and Korooni Z.., 2015. Factors Affecting Pistachio Export Earnings Instability and $i$ its Effect on Agricultural Exports, International Journal of Agricultural Management and Development (IJAMAD)

4. Muthamia A.K. dan Muturi W. (2015), Determinants of Earnings from Tea Export in Kenya: 1980-2011, International Journal of Agricultural Management and Development (IJAMAD).

5. Puslitkoka, 2016. Pusat Penelitian Kopi dan Kakao, Jember.

6. Trademap. Trade Statistics for International Business Development, http://www.trademap.org.

7. UN Comtrade. United Nations Comtrade Database - International Trade Statistics https://comtrade.un.org/ 